\title{
The Effect of Steroid Therapy for Idiopathic Unilateral Vocal Cord Palsy
}

\author{
Jong-Won Bae (D) and GilJoon Lee (D) \\ Department of Otorhinolaryngology-Head and Neck Surgery, Chilgok Kyungpook National University Hospital, Kyungpook National University \\ School of Medicine, Daegu, Korea
}

\section{특발성 일측성 성대마비에서 경구 스테로이드 요법의 효과}

배종원, 이길준

경북대학교 의과대학 칠곡경북대학교병원 이비인후-두경부외과학교실

Background and Objectives Idiopathic unilateral vocal fold paralysis (IVFP) is believed to be due to inflammation and edema of the recurrent laryngeal nerve caused by viral diseases such as upper respiratory tract infections. Corticosteroid has a potent anti-inflammatory action which should minimize nerve damage. The purpose of this study was to investigate the effect of oral steroid therapy on IVFP.

Materials and Method Study was performed for the IVFP patient from January 2012 to August 2017. Patient's dermography, direction and location of paralyzed vocal cords, history of hypertension, diabetes, cerebrovascular disease, and other underlying disease, smoking history, alcohol consumption and upper respiratory tract infection, and symptoms were investigated. Treatment was divided into three groups: the observation group, low-dose group, and high-dose group, and the recovery rate and time of vocal cord paralysis were analyzed in each group.

Results Thirty-seven patients were enrolled in this study. There was no relationship between oral steroid use, dosage and recovery of vocal cord paralysis. Oral steroids showed a rapid recovery of vocal cord paralysis, but there was no statistically significant difference in the time of recovery of vocal palsy with or without steroids ( $p=0.673$ ). In addition, there was no statistically significant difference in recovery rate between the period to start of treatment, presence of diabetes mellitus, and treatment modality, but the recovery rate was high in the group with upper respiratory tract infection history $(p=0.041)$.

Conclusion In IVFP, oral steroid therapy has no significant difference in time and extent of recovery compared to the case of spontaneous recovery.

Keywords Unilateral vocal cord paralysis; Larynx; Steroids.

\section{서 론}

성대마비는 성대를 움직이는 근육이나 이를 지배하는 신경의 기능 이상으로 인하여 성대가 움직이지 않는 상태를 뜻한다. 성대 움직임을 관장하는 반회후두신경(recurrent laryngeal nerve)의 마비를 야기는 폐, 식도 및 인접 림프절의 종양성 질환, 외상, 종격동

\author{
Received October 15, 2019 \\ Revised October 18, 2019 \\ Accepted November 29, 2019 \\ Corresponding Author \\ GilJoon Lee, MD \\ Department of Otorhinolaryngology- \\ Head and Neck Surgery, \\ Chilgok Kyungpook National \\ University Hospital, \\ Kyungpook National University \\ School of Medicine, \\ 807 Hoguk-ro, Buk-gu, \\ Daegu 41404, Korea \\ Tel $+82-53-200-2166$ \\ Fax +82-53-200-2027 \\ E-mail giljoon.lee@gmail.com
}

\section{ORCID iDs}

Jong-Won Bae (D)

https://orcid.org/0000-0002-0874-0623

GilJoon Lee (D)

https://orcid.org/0000-0002-3344-1879

\author{
This is an Open Access article distributed \\ under the terms of the Creative \\ Commons Attribution Non-Commercial \\ License (https://creativecommons.org/ \\ licenses/by-nc/4.0) which permits \\ unrestricted non-commercial use, \\ distribution, and reproduction in any \\ medium, provided the original work is \\ properly cited.
}


의 염증성 질환, 그리고 갑상선 수술 등 수술 과정에서 발생 하는 의인성 신경손상 등을 성대마비의 원인으로 들 수 있다. 반회후두신경 마비로 인한 성대마비 외에도 기관 삽관이나 외상 등으로 인한 피열연골탈구(arytenoid cartilage dislocation) 등에 의해서도 성대마비가 발생할 수 있다..$^{1-3)}$ 이러한 원인들 외 기질적인 병인 없이 특발성으로 발생하는 성대마비 도 있으며 60 70\% 이상에서 자연적으로 회복되는 것으로 알 려져 있다. 특발성 성대마비로 진단된 환자들 중 감기와 같은 상기도 감염의 병력이나 수면 부족, 신체의 과도한 피로감 등 이 확인되는 경우가 많아 바이러스성 질환에 의한 반회후두 신경마비가 원인으로 거론되지만 논란이 있는 상태이다. ${ }^{4-6)}$ 특발성 성대마비는 대부분 일측성으로 발생하며, 호흡곤란이 나 연하 시 지속적인 흡인과 같이 즉각적인 치료를 요하는 양 측성 성대마비와 달리 특별한 증상이 없거나 음성 변화나 경 부 이물감 등의 경미한 증상을 호소하는 경우가 많다. ${ }^{7}$ 특발 성 일측성 성대마비의 경우 심각한 증상이 없고 $60 \%$ 이상에 서 자연 회복되기 때문에 특별한 치료를 하지 않거나 음성 치 료를 시행하는 경우가 많고 1년 정도 경과하여도 호전이 없는 경우 성대주입술(injection thyroplasty)이나 후두골격 수술 (laryngeal framework surgery)을 시행한다. 실제 임상에서 음성 변화, 경부 이물감과 같은 증상의 빠른 개선을 원하는 경우나 성대마비의 회복 가능성에 대한 불안감을 해소하기 위 해 치료를 원하지만 치료 과정에 소요되는 시간, 음성 치료 비 용에 대한 경제적인 부담, 수술적 치료에 대한 거부감 등으로 인해 기존 치료법으로 알려진 경과 관찰, 음성 치료, 성대 수술 을 거부하는 경우를 경험한다. ${ }^{89)}$ 특발성 일측성 성대마비가 상기도 감염이나 피로감 등 면역력이 저하되어 있는 상황에서 바이러스에 의해 발생하였을 경우를 가정하여 경구 스테로이 드 요법이 성대마비 회복에 영향을 줄 수 있을 것으로 판단하 여, 이에 저자들은 경구 스테로이드 요법이 특발성 일측성 성대 마비에 미치는 영향을 알아보기 위해 본 연구를 진행하였다.

\section{대상 및 방법}

2012년 1월 2017년 8월까지 이비인후과 외래에서 굴곡형 후두내시경을 통해 일측성 성대마비로 진단받은 환자 중 갑 상선을 포함한 두경부 수술, 심장, 폐, 식도 관련 흥부외과 수 술 등의 병력이 없으며 경부 방사선 조사력, 외상의 병력이 없 고 경부 CT를 통해 두개저부터 폐, 식도에 걸쳐 신경 주행 상 종양 등의 기질성 병변이 없는 특발성 일측성 성대마비 환자 들을 대상으로 하였다. 이들 중 성대마비의 회복 여부를 판단 하기 위해 1년 이상 추적 관찰 가능하였던 37명의 환자들을 대 상으로 하였다.
환자들의 성별, 나이, 마비된 성대의 방향, 위치와 고혈압, 당뇨병, 뇌혈관질환 등의 기저질환 병력, 흡연력, 음주력, 상기 도 감염 여부 등을 조사하였고 성대마비로 진단된 당시 호소 하였던 증상 또한 조사하였다. 치료는 특별한 약물이나 시술 없이 경과 관찰한 경과 관찰군, methylprednisolone $4 \mathrm{mg}$ 을 1일 2회 7일간 경구 복용하도록 한 저용량군(총 $56 \mathrm{mg}$ ), methylprednisolone $48 \mathrm{mg}$ 1일 1회 7일간 복용 후 4일에 걸 쳐 $32,24,16,8 \mathrm{mg}$ 으로 순차적으로 감량하여 복용하도록 한 고용량군(총 $416 \mathrm{mg})$ 으로 나누어 시행하였고 성대마비의 호전 여부 및 호전되기까지 걸린 시간을 조사하여 비교 분석 하였다.

통계분석은 SAS ver. 9.2(SAS Institute Inc., Cary, NC, USA) 프로그램을 이용하였고 피어슨 카이 제곱 검정, Kruskal-wallis test, 다변수 로지스틱 회귀분석(multivariate logistic regression analysis)을 사용하였다. 분석값의 유의 수준은 $\mathrm{p}<$ 0.05 를 기준으로 하였다.

\section{결 과}

37 명의 평균 연령은 48.3세였고 성비는 남성 22명(59.5\%), 여 성 15 명(40.5\%)으로 나타났다. 성대마비의 방향은 우측이 14 명 (37.8\%), 좌측이 23명(62.2\%)였고 마비된 성대의 위치는 median 17명(45.9\%), paramedian 6명(16.2\%), intermediate 14명 (37.9\%)이었다. 기저질환으로 고혈압을 않고 있는 환자는 7명 (18.9\%), 당뇨병은 8명(21.6\%), 뇌혈관질환은 4명(10.8\%)에서 확인되었다. 흡연력상 현재 흡연자는 11명(29.7\%), 5년 미만 금 연자는 5명(13.5\%), 5 년 이상 금연자는 6명(16.2\%), 비흡연자 는 15 명 (40.5\%)였다. 음주력상 주 1 회 이상 음주를 하는 환자 는 6명(16.2\%), 월 1회 이상 음주를 하는 환자는 16명(43.2\%), 현재 금주를 하고 있는 환자 8명(21.6\%), 비음주자는 7명(18.9\%) 으로 나타났다. 전체 환자의 64.9\%인 24명이 성대마비로 진단 받기 2주 이내 상기도 감염을 않았던 병력이 있었다. 성대마비 진단 당시 호소하였던 증상은 마른 기침 23명(62.2\%), 음성 변 화 18명(48.6\%), 인후 이물감 18명(48.6\%), 사레 4명(10.8\%), 연하곤란 3명(8.1\%)으로 조사되었다. 성대마비가 발생한 시점 을 평가하기 위해 증상이 발생한 시점부터 병원에 내원하여 치 료를 시작하기까지의 기간을 조사하였고 평균 25.9일이었으며 7일 이내에 치료를 시작한 환자가 8명(21.6\%), 7일 초과 30일 이내에 치료를 시작한 환자가 18명(48.6\%), 30일 초과한 환자 는 11명(29.7\%)인 것으로 나타났다(Table 1).

성대마비의 회복은 굴곡형 후두내시경으로 관찰하였을 때 진성대 및 피열연골의 움직임이 관찰된 경우로 정의하였다. 37 명의 환자 중 26 명(70.3\%)이 회복되었고 그룹별로 분석하 
Table 1. Clinical characteristics of unilateral vocal cord palsy patients Clinical features $(n=37)$ Age (years) $48.3(29-80)$

Sex

$\begin{array}{ll}\text { Male } & 22(59.5) \\ \text { Female } & 15(40.5) \\ \text { Location } & \\ \text { Right } & 14(37.8) \\ \text { Left } & 23(62.2)\end{array}$

Position

Median

$17(45.9)$

Paramedian

$6(16.2)$

Intermediate

$14(37.9)$

Smoking

Yes

$11(29.7)$

Stop smoking $<5$ years

$5(13.5)$

Stop smoking $\geq 5$ years

$6(16.2)$

No

$15(40.5)$

Alcohol intake

$\geq 1$ per week $6(16.2)$

$\geq 1$ per month $\quad 16(43.3)$

Stop drinking $8(21.6)$

No 7 (18.9)

Past medical history

Hypertension $26(50.0)$

Diabetes mellitus $\quad 5$ (9.6)

Cardiovascular disease $25(48.1)$

Upper respiratory infection ( $\leq 2$ weeks)

Yes

$24(64.9)$

No

$13(37.8)$

Symptoms

\begin{tabular}{lc} 
Cough & $23(62.2)$ \\
Voice change & $18(48.6)$ \\
Globus sensation & $18(48.6)$ \\
Aspiration & $4(10.8)$ \\
Swallowing difficulty & $3(8.1)$ \\
\hline Period (symptom-treatment, day) & $25.9(3-120)$
\end{tabular}

Period (symptom-treatment, day) 25.9 (3-120)

Variables are presented as number (percentage) or mean (range)

였을 때 경과 관찰군은 총 20 명 중 14 명(70\%)에서 호전을 보 였고 저용량군은 11 명 중 8 명 $(72.7 \%)$, 고용량군은 6 명 중 4명 (66.7\%)이 성대마비에서 회복되었으며 경구 스테로이드 사용 여부 및 용량 변화와 성대마비의 회복은 관계가 없는 것으로 조사되었다. 성대마비에서 회복되는 데까지 걸린 시간은 경과 관찰군이 평균 2.14 개월, 저용량군이 1.60 개월, 고용량군이 1.75 개월로 나타났다. 경구 스테로이드를 사용한 군에서 성대마비 가 회복되기까지 평균 1.67 개월이 소요되어 경과 관찰군보다 빠른 회복 속도를 보였으나 스테로이드를 사용하지 않은 경 우와 스테로이드의 용량의 차이에 따른 성대마비의 회복 속
Table 2. Clinical outcomes of unilateral vocal cord palsy

\begin{tabular}{|c|c|c|c|c|}
\hline & Observation & $\begin{array}{c}\text { Low dose } \\
\text { steroid }\end{array}$ & $\begin{array}{l}\text { High dose } \\
\text { steroid }\end{array}$ & $\begin{array}{c}\mathrm{p} \\
\text { value }\end{array}$ \\
\hline No. of patients & 20 & 11 & 6 & \\
\hline Recovery & $14(70)$ & $8(72.7)$ & $4(66.7)$ & \\
\hline $\begin{array}{l}\text { ecovery time } \\
\text { (month) }\end{array}$ & 2.14 & 1.60 & 1.75 & 0.673 \\
\hline
\end{tabular}

Variables are presented as number (percentage) or mean

Table 3. Multivariate logistic regression analysis for recovery of unilateral vocal cord palsy

\begin{tabular}{|c|c|c|c|}
\hline Variable & OR & $95 \% \mathrm{CI}$ & p value \\
\hline \multicolumn{4}{|c|}{ Period (symptom-treatment) } \\
\hline$<7$ days & 1 & & \\
\hline 7-30 days & 1.049 & $0.731-1.384$ & 0.512 \\
\hline$>30$ days & 0.943 & $0.472-1.469$ & 0.465 \\
\hline \multicolumn{4}{|l|}{ URI history } \\
\hline No & 1 & & \\
\hline Yes & 1.426 & $1.091-1.786$ & $0.041^{*}$ \\
\hline \multicolumn{4}{|l|}{$\mathrm{DM}$} \\
\hline No & 1 & & \\
\hline Yes & 0.896 & $0.354-1.293$ & 0.847 \\
\hline \multicolumn{4}{|l|}{ Treatment modality } \\
\hline Observation & 1 & & \\
\hline Low dose steroid & 1.128 & $0.827-1.514$ & 0.369 \\
\hline High dose steroid & 0.798 & $0.467-1.162$ & 0.716 \\
\hline
\end{tabular}

${ }^{*} \mathrm{p}<0.05$. URI: upper respiratory infection, DM: diabetes mellitus, CI: confidence interval, OR: odds ratio

도에 대해서는 통계적으로 유의한 차이가 없었다 $(\mathrm{p}=0.673)$

(Table 2).

여러 독립변수들 중 치료 시작 시점까지의 기간, 상기도 감 염 유무, 당뇨병 유병 유무, 치료 방법 등의 변수를 대상으로 다변량 로지스틱 회귀분석을 시행하였다. 치료 시작까지의 기간이 7 30일인 경우 7일 이내 시작한 환자에 비해 성대마 비가 1.049배 호전되었으며 30일을 초과한 경우 7일 이내 시 작한 환자에 비해 회복율은 0.943배로 감소하였다. 하지만 통 계학적으로 유의한 차이는 없었다. 상기도 감염의 경우 상기 도 감염의 병력이 있는 환자군에서 1.426 배 회복률이 높은 것 으로 나타났고 이는 통계학적으로 의미 있는 것으로 조사되 었다 $(\mathrm{p}=0.041)$. 당뇨병이 있는 경우에는 회복률이 0.896배로 감소하는 것으로 나타났으나 통계적으로 유의한 차이는 없었 다 $(\mathrm{p}=0.847)$. 치료 방법에 따라서 경과 관찰군, 저용량 스테로 이드군, 고용량 스테로이드군에 대해 회복률을 조사하였고 경과 관찰군에 비해 저용량 스테로이드군에서 1.128 배 회복률 이 증가하는 것으로 조사되었고 고용량 스테로이드군은 0.798 배 감소하는 것으로 나타났다. 하지만 통계학적으로 치료 방법 에 따른 회복률이 차이는 없는 것으로 조사되었다(Table 3). 


\section{고 찰}

특발성 일측성 성대마비의 경우 기질적 원인이 없고 상당 수에서 자연 회복되기 때문에 일반적으로 적극적인 치료를 하지 않고 경과 관찰하며 성대 움직임의 변화 여부를 확인한 다. ${ }^{1,2,10,11)}$ 양측성 성대마비와 같이 호흡곤란이나 흡인 등의 심각한 증상이 없는 경우가 많지만 목소리 변화, 목의 이물감, 기침 등의 증상을 호소하는 경우가 많고 성대 움직임이 회복 되지 않을 가능성에 대한 두려움 때문에 치료를 원하는 환자 들이 많다. ${ }^{6,11)}$ 특발성 일측성 성대마비의 치료는 크게 음성 치 료와 수술적 치료로 나뉜다. 음성 치료는 1차적으로 고려되는 치료로 성대마비의 시기에 관계 없이 시행된다. ${ }^{12)}$ 수술적 치료 는 일반적으로 성대마비의 자연 회복 가능성이 낮아지는 1 년 을 기준으로 1 년 이상 회복이 없는 경우 고려되며 그 외 일상 생활에 지장을 주는 음성 변화, 사레가 심해서 흡인 증상이 지 속되는 경우 등에도 시행된다. ${ }^{13)}$ 하지만 실제 임상 진료에서는 적극적인 치료를 원하지만 음성 치료나 수술적 치료를 시행하 기 힘든 환자들이 있고 이에 본 연구를 계획하였다. 경구 스테 로이드 요법은 감기나 과로, 수면 부족 등으로 인한 신체 면역 력 저하가 특발성 성대마비에 영향을 미칠 것으로 판단하여 시행하였다. 하지만 환자의 면역력 저하를 판단할 객관적인 지표가 없이 문진상 주관적인 표현에 근거하였다는 점은 한 계점으로 지적된다. 또한 스테로이드 치료한 군과 특별한 치 료 없이 경과 관찰한 군을 비교하였는데 당뇨병이 있는 환자 에서는 고용량 스테로이드 치료를 시행하지 못한 점, 스테로 이드 용량별로 군을 나누었는데 각 군 간의 환자수가 고르게 분포되지 못한 점 그리고 음성 치료나 수술적 치료 등 다른 치 료를 시행한 군과 비교, 분석하지 않았다는 것 또한 연구의 한 계점으로 지적할 수 있다. 현실적으로 음성 치료나 수술적 치 료를 시행하기 힘든 상황에서 경구 스테로이드 요법이 특발성 일측성 성대마비의 회복에 미치는 영향을 조사하였으나 자연 회복되는 경우와 비교하여 회복 시기를 단축시키거나 호전율 을 높이는 효과는 없는 것으로 나타났다. 본 연구에서 분석한 변수들 중 상기도 감염의 병력 여부가 성대마비의 회복에 관 계가 있는 것으로 조사되었는데 이는 바이러스 감염으로 인한 일시적 성대마비가 전신 상태의 호전에 따라 회복되었을 가 능성을 시사한다고 사료된다. 또한 임상 진료에서 특발성 일 측성 성대마비를 진단하는 과정에서 상기도 감염의 병력을 반드시 확인하는 과정이 필요하며 상기도 감염에 따른 바이 러스와 성대마비의 연관성에 대한 추가적인 연구가 이루어져 야 할 것이다. 특발성 일측성 성대마비의 경우 치료법이나 자 연 회복률 등 임상 경과에 대한 명확한 결론이 도출된 것을 없 고 여러 연구를 통해 다양한 결과들이 보고되고 있다. ${ }^{14)}$ 이에
대한 체계적인 후속 연구가 뒤따라야 할 것이다.

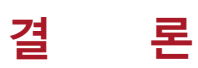

특발성 일측성 성대마비에서 경구 스테로이드 요법은 자연 회복되는 경우와 비교하였을 때 회복되는 시기나 정도에 차 이가 없으며 제한적이지만 상기도 감염의 병력 유무가 성대마 비 회복율에 영향을 미치는 것으로 사료된다.

중심 단어: 일측성 성대마비, 후두, 스테로이드.

Acknowledgments,

None.

Conflicts of Interest

The authors have no financial conflicts of interest.

Authors' Contribution

Conceptualization: GilJoon Lee. Data curation: Jong-Won Bae, GilJoon Lee. Formal analysis: Jong-Won Bae, GilJoon Lee. Investigation: GilJoon Lee. Methodology: Jong-Won Bae, GilJoon Lee. Project administration: GilJoon Lee. Resources: GilJoon Lee. Software: GilJoon Lee. Supervision: GilJoon Lee. Validation: GilJoon Lee. Visualization: GilJoon Lee. Writing_original draft: Jong-Won Bae, GilJoon Lee. Approval of final manuscript: all authors.

\section{REFERENCES}

1. Anil HT, Lasya Raj N, Pillai N. A study on etiopathogenesis of vocal cord paresis and palsy in a tertiary centre. Indian J Otolaryngol Head Neck Surg 2019;71(3):383-9.

2. Masroor F, Pan DR, Wei JC, Ritterman Weintraub ML, Jiang N. The incidence and recovery rate of idiopathic vocal fold paralysis: a population-based study. Eur Arch Otorhinolaryngol 2019;276(1):153-8.

3. Rasmussen ER, Mey K. Vocal cord paralysis associated with Ramsay Hunt syndrome: looking back 50 years. BMJ Case Rep 2014;2014. bcr2013201038.

4. Rubin F, Villeneuve A, Alciato L, Slaïm L, Bonfils P, Laccourreye O. Idiopathic unilateral vocal-fold paralysis in the adult. Eur Ann Otorhinolaryngol Head Neck Dis 2018;135(3):171-4.

5. Kwon M, Bae MR, Lee YS, Roh JL, Choi SH, Nam SY, et al. Idiopathic unilateral vocal fold paralysis in older patients: characteristics in the disease course and implication of computed tomography for evaluation of etiology. Ann Otol Rhinol Laryngol 2018;127(11):823-8.

6. Bhatt NK, Pipkorn P, Paniello RC. Association between upper respiratory infection and idiopathic unilateral vocal fold paralysis. Ann Otol Rhinol Laryngol 2018;127(10):667-71.

7. Cantarella G, Dejonckere P, Galli A, Ciabatta A, Gaffuri M, Pignataro L, et al. A retrospective evaluation of the etiology of unilateral vocal fold paralysis over the last 25 years. Eur Arch Otorhinolaryngol 2017;274(1):347-53.

8. Hojjat H, Svider PF, Folbe AJ, Raza SN, Carron MA, Shkoukani MA, et al. Cost-effectiveness of routine computed tomography in the evaluation of idiopathic unilateral vocal fold paralysis. Laryngoscope 2017;127(2):440-44.

9. Tibbetts KM, Wu D, Hsu JV, Burton WB, Nassar M, Tan M. Etiology and long-term functional swallow outcomes in pediatric unilateral vocal fold immobility. Int J Pediatr Otorhinolaryngol 2016;88:179-83.

10. Chang WH, Fang TJ, Li HY, Jaw FS, Wong AM, Pei YC. Quantitative electromyographic characteristics of idiopathic unilateral vocal fold 
paralysis. Laryngoscope 2016;126(11):E362-8.

11. Spataro EA, Grindler DJ, Paniello RC. Etiology and time to presentation of unilateral vocal fold paralysis. Otolaryngol Head Neck Surg 2014;151(2):286-93.

12. Reiter R, Pickhard A, Sander S, Brosch S. Prognostic relevance of mucosal waves in patients with unilateral vocal fold paralysis. Ann Otol Rhinol Laryngol 2016;125(4):331-5.
13. Francis DO, Williamson K, Hovis K, Gelbard A, Merati AL, Penson $\mathrm{DF}$, et al. Effect of injection augmentation on need for framework surgery in unilateral vocal fold paralysis. Laryngoscope 2016;126(1):12834.

14. Mau T, Pan HM, Childs LF. The natural history of recoverable vocal fold paralysis: implications for kinetics of reinnervation. Laryngoscope 2017;127(11):2585-90. 